\title{
Numerical Taxonomy of the Yeast Genus Debaryomyces Lodder \& Kreger-van Rij
}

\author{
By ANNA KOCKOVÁ-KRATOCHVÍLOVÁ AND ELENA SLÁVIKOVÁ \\ Institute of Chemistry of the Slovak Academy of Sciences, \\ Bratislava, Czechoslovakia \\ AND VAGN JENSEN \\ Royal Veterinary and Agricultural University, Copenhagen, Denmark
}

(Received 26 May 1977 ; revised 30 August 1977)

\begin{abstract}
A set of 142 strains of yeasts, originally described as Debaryomyces species, were examined for 64 morphological, physiological and serological characters and the results were subjected to numerical analysis. Three phenons and one individual strain emerged at the $77 \%$ similarity level. The first two phenons were each divided into three subphenons at the $85 \%$ similarity level. Assimilation of $n$-alkanes $\left(\mathrm{C}_{6}\right.$ to $\left.\mathrm{C}_{16}\right)$ was most useful for the division of strains into the three phenons. The data agree with the published results of $\% \mathrm{GC}$ content.
\end{abstract}

\section{INTRODUCTION}

The genus Debaryomyces Lodder \& Kreger-van Rij comprises yeasts with globose or ellipsoidal cells, which reproduce by multilateral budding. Pseudomycelium may be formed. Heterogamous conjugation, between mother cell and bud, generally precedes ascus formation, but isogamous conjugation also occurs. The spores are spherical or oval with 'warty' walls. One or two spores are usually formed per ascus but in some species up to four may be present. Fermentation is slow, weak or absent; nitrate is not assimilated (Lodder, 1970).

Debaryomyces species are ubiquitous, occurring in soil, in water, on plants etc. They assimilate a large number of sugars and polyols, including pentoses, starch and inulin (Lodder, 1970) and phenol and catechol (Rao \& Bhat, 1971). Strains are osmophilic and halophilic, tolerating more than $24 \% \mathrm{NaCl}$ in the medium (Norkrans, 1966, 1968; Norkrans \& Kylin, I969; Gezelius \& Norkrans, 1970). Some strains accumulate a considerable amount of riboflavin (Shavlovsky, Ksheminskaya \& Varivoda, 1970). Only little is known about hydrocarbon utilization by Debaryomyces species: Markowetz \& Kallio (1964) showed that D. kloeckerii utilizes pure hydrocarbons and kerosene; Scheda \& Bos (1966) showed the same for D. hansenii and D. vanriji; but Komagata, Nakase \& Katsuya (1964) did not detect utilization of kerosene in any of 36 strains of five species of the genus Debaryomyces.

This paper presents the results of the numerical evaluation of 142 strains of Debaryomyces on the basis of 64 characters.

\section{METHODS}

Organisms. All strains (see Table I) originated from the Czechoslovak Collection of Yeasts (CCY), Institute of Chemistry SAS, Bratislava.

Tests. The 64 morphological, physiological, genetical and immunological characters employed in the analysis were tested following the methods of Kocková-Kratochvilová et al. (1969).

Cell morphology. Lengths and widths of 100 to 200 cells from a 3-day-old culture in beer wort $(7 \%$, 
Table I. Strains studied

CCY no.t

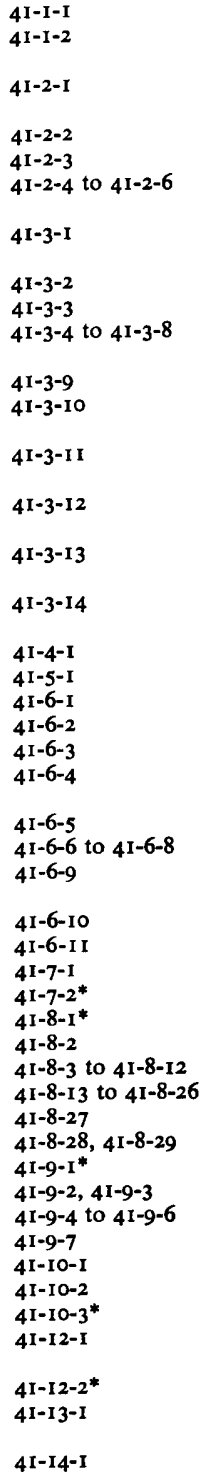

4I-I4-I

4I-I 5-I to $4 I-15-3$

$4 I-I 5-4$ to $4 I-15-5$

$4 I-15-6$ to $4 I-15-8$

$4 \mathrm{I}-\mathrm{I} 5-9,4 \mathrm{I}-\mathrm{I}$ - $\mathrm{IO}$

D. formicarius Golubev \& Babyeva

4I-15-1I to 4I-15-20 D. formicarius Golubev \& Babyeva

$4 I-15-2 I$

$4 \mathrm{I}-15-22 *$

4I-I6-I

4I-16-2

4I-I 7-I

$4 I-17-2,4 I-17-3$

$4 I-18-I$

4I-I9-I

4I-20-I D. nicotinae Giovannozzi

D. globosus Klöcker

D. globosus Klöcker

D. globosus Klöcker

D. kloeckeri Guilliermond \& Péju

D. kloeckeri Guilliermond \& Péju

D. kloeckeri Guilliermond \& Péju

D. kloeckeri Guilliermond \& Péju

D. kloeckeri Guilliert

\& Péju race fabryi)

\& Péju race gruetzii)

\& Péju race hildegardii)

Naganishi var. hollandicus Lodder) var. hansenii)

D. phaffii Capriotti

D. phaffii Capriotti

D. cantarellii Capriotti

D. cantarellii Capriotti

D. cantarellii Capriotti

D. cantarellii Capriotti

D. cantarellii Capriotti

D. cantarellii Capriotti

D. castellii Capriotti

D. castellii Capriotti

D. castellii Capriotti

D. castellii Capriotti

D. marama di Menna

D. marama di Menna

D. marama di Menna

D. coudertii Saëz

D. coudertii Saëz

D. formicarius Golubev \& Babyeva

D. formicarius Golubev \& Babyeva

D. formicarius Golubev \& Babyc

D. formicarius Golubev \& Babyeva
D. formicarius Golubev \& Babyeva

D. formicarius Golubev \& Babyeva

Miller \& Shifrine)

Miller \& Shifrine)

(Saito) Lodder \& Kreger-van Rij]

Rij]

D. guilliermondii Dekker

\section{Original name}

Debaryomyces nicotianae Giovannozzi var. minor Giovannozzi

Saccharomyces kloeckerianus van der Walt

D. kloeckeri Guilliermond \& Péju race $S$

D. kloeckeri Guilliermond \& Péju (syn. D. matruchoti Grigoraki

D. kloeckeri Guilliermond \& Péju (syn. D. matruchoti Grigoraki

D. kloeckeri Guilliermond \& Péju (syn. D. matruchoti Grigoraki

D. kloeckeri Guilliermond \& Péju (syn. D. membranaefaciens

D. subglobosus (Zach) Lodder \& Kreger-van Rij

D. vini Zimmermann (syn. Pichia vini)

D. hansenii (Zopf) Lodder \& Kreger-van $\mathrm{Rij}$

D. hansenii (Zopf) Lodder \& Kreger-van Rij

D. hansenii (Zopf) Lodder \& Kreger-van $\mathbf{R i j}$

D. hansenii (Zopf) Lodder \& Kreger-van Rij

D. hansenii (Zopf) Lodder \& Kreger-van Rij

D. hansenii (Zopf) Lodder \& Kreger-van Rij

D. hansenii (Zopf) Lodder \& Kreger-van Rij (syn. D. tyrocola

D. hansenii (Zopf) Lodder \& Kreger-van Rij

D. hansenii (Zopf) Lodder \& Kreger-van Rij

D. franciscae (Capriotti) Kodama, Kyono, Naganishi \&

Takahara (Saccharomyces pretoriensis van der Walt \& Tscheuschner)

D. nilssonii (Capriotti) Kodama, Kyono, Naganishi \& Takahara (Saccharomyces microellipsodes Osterwalder)

D. manchuricus Naganishi (Saccharomyces montanus Phaff,

D. manchuricus Naganishi (Saccharomyces montanus Phaff,

D. dekkeri Mrak et al. ex Kudriavzev [Saccharomyces fermentati

D. dekkeri Mrak et al. ex Kudriavzev

D. delbrueckii (Lindner) Kudriavzev (syn. Torulaspora delbrueckii

Lindner, Saccharomyces delbrueckii Lindner)

D. disporus Dekker [Saccharomyces disporus (Dekker) Kreger-van
Origin $\dagger$ and date

BI CZAS 365 (1957)

Isolated from mushroom Pluteus

nannus in Kuřim (1962)

Carlsberg Lab., Copenhagen,

Denmark (1947)

CBS (1947)

LKB-D-I（1973）

VKM-Y-92, VKM-Y-I035, VKM-Y-93

(r973)

Carlsberg Lab., Copenhagen,

Denmark (1947)

BI CZAS 364/2 (1957)

MGU 1923 (1973)

VKM-Y-96, VKM-Y-IO42 to VKM-Y-I045

(I973)

VKM-Y-I046 (1973)

VKM-Y-IOI (I973)

VKM-Y-IO2 (1973)

VKM-Y-I03 (1973)

VKM-Y-104 (1973)

VKM-Y-I08 (1973)

BI CZAS 363 (1957)

NRRL Y-I459 (1970)

BI CZAS 36I/I (I95I)

BI CZAS 361/2 (I95I)

BI CZAS 36I/3 (I95I)

Plant sample (Mecklenburg, GDR)

(197I)

LKB-D-774 (1973)

MGU 2367 to MGU 2369 (I973)

VKM-Y-I 6 (1973)

VKM-Y-IO4O (I973)

LKB-D-I (1973)

IFO I362 (I969)

CBS 4346 (1973)

NRRL YB-5160 (1970)

LKB-D-2 (1973)

MGU 2397 to MGU 2406 (1973)

MGU 2407 to MGU 2420 (1973)

MGU 2433 (I973)

VKM-Y-I 562, VKM-Y-I 563 (1973)

NRRL Y-5983 (I970)

MGU 2431, MGU 2432 (1973)

MGU 2449 to MGU 245I (1973)

MGU A-I 28 (I973)

NRRL Y-217I (1970)

VKM-Y-IOO (1973)

CBS 1958 (1973)

Plant sample (Mecklenburg, GDR)

(197I)

CBS 5 I67 (1973)

LKB-D-3 (1973)

LKB-D-637 (1973)

MGU 2342 to MGU 2344 (1973)

MGU 2346, MGU 2347 (I973)

MGU 2349 to MGU 235 I (1973)

MGU 2354, MGU 2355 (1973)

MGU 2357 to MGU 2366 (1973)

IBPM 650 (1973)

VKM-Y-I 555 (I973)

IBPM 240 (1973)

VKM-Y-99 (1973)

IBPM 235 (I973)

VKM-Y-9I, VKM-Y-707 (1973)

VKM-Y-706 (1973)

VKM-Y-I034 (1973)

VKM-Y-94 (I973) 
Table I. (cont.)

\begin{tabular}{|c|c|c|}
\hline CCY no. $\dagger$ & Original name & Origin $\dagger$ and date \\
\hline $4 I \cdot 20-2$ & D. guilliermondii Dekker & VKM-Y-1036 (1973) \\
\hline $41-20-3$ & D. guilliermondii Dekker (syn. D. kloeckeri var. major) & VKM-Y-97 (1973) \\
\hline $41-20-4$ & $\begin{array}{l}\text { D. guilliermondii Dekker (syn. D. matruchoti var. subglobosus } \\
\text { Zach) }\end{array}$ & VKM-Y-106 (1973) \\
\hline $41-20-5,41-20-6$ & D. guilliermondii Dekker (syn. D. tyrocola) & VKM-Y-IO52, VKM-Y-1053 (1973) \\
\hline $41-20-7$ & D. guilliermondii Dekker (syn. D. tyrocola strain ' $\mathrm{Sb}$ ') & VKM-Y-I I 5 (1973) \\
\hline $41-20-8$ & D. guilliermondii Dekker & VKM-Y-1037 (1973) \\
\hline $4 \mathrm{I}-20-9,4 \mathrm{I}-20-10$ & D. guilliermondii Dekker var. nova-zeelandicus Lodder & VKM-Y-1039, VKM-Y-1038 (1973) \\
\hline $4 I-2 I-1$ & D. hudeloi da Fonseca (syn. D. kloeckeri Guilliermond \& Péju) & VKM-Y-95 (1973) \\
\hline 4I-22-1 & D. konokotinae Kudriavzev & VKM-Y-98 (I973) \\
\hline $4 I-23-1$ to $4 I-23-3$ & D. mucosus [Torulopsis candida (Sito) Lodder] & $\begin{array}{l}\text { VKM-Y-I047, VKM-Y-I048, VKM-Y-109 } \\
\text { (1973) }\end{array}$ \\
\hline $4 I-24-1$ to $4 \mathrm{I}-24-3$ & $\begin{array}{l}\text { D. rosei (Guilliermond) Kudriavzev (syn. Torulaspora rosei } \\
\text { Guilliermond) }\end{array}$ & $\begin{array}{l}\text { VKM-Y-1049, VKM-Y-708, VKM-Y-710 } \\
\text { (1973) }\end{array}$ \\
\hline $41-24-4$ & $\begin{array}{l}\text { D. rosei (Guilliermond) Kudriavzev (syn. Zygosaccharomyces } \\
\text { globiformis forma typica Kroemer) }\end{array}$ & VKM-Y-864 (1973) \\
\hline $4 I-25-I$ & D. sake Saito \& Ota. & VKM-Y-IO5O (I973) \\
\hline $4 I-26-I, 4 I-26-2$ & D. tyrocola Konokotina & VKM-Y-I I3, VKM-Y-II 2 (1973) \\
\hline $41-26-3$ & D. tyrocola Konokotina race ' $O P$ ' & VKM-Y-IO5I (1973) \\
\hline $4 I-26-4$ & D. tyrocola Konokotina & VKM-Y-1054 (1973) \\
\hline $41-26-5$ & D. tyrocola Konokotina (syn. D. matruchoti var. cesarii Dekker) & VKM-Y-105 (1973) \\
\hline $4 I-26-6$ & D. tyrocola Konokotina (syn. D. membranaefaciens Naganishi) & VKM-Y-107 (1973) \\
\hline $41-26-7$ & D. tyrocola Konokotina (syn. D. nicotianae Giovannozzi) & VKM-Y-I IO (1973) \\
\hline $41-26-8$ & D. tyrocola Konokotina (syn. D. nicotianae var. minor Giovannozzi) & VKM-Y-III (I973) \\
\hline $4 I-27-1$ & $\begin{array}{l}\text { D. cavensis Giovannozzi [syn. D. hansenii (Zopf) Lodder \& } \\
\text { Kreger-van Rij] }\end{array}$ & VKM-Y-90 (1973) \\
\hline $4 I-28-I^{*}$ & D. tamarii Ohara \& Nonomura & CBS 4333 (1973) \\
\hline $4 I-29-I^{*}$ & D. nepalensis Goto & CBS 5921 (1973) \\
\hline $41-29-2 *$ & D. nepalensis Goto & NP-2-17-5, S. Goto, Japan (1973) \\
\hline $4 I-30-I^{*}$ & D. yarrowii Santa María \& Aser & CBS 6246 (1973) \\
\hline \multicolumn{3}{|c|}{$\begin{array}{l}\text { * Type culture. } \\
\text { † BI CZAS, Biological Institute of the Czechoslovak Academy of Sciences, Prague, Czechoslovakia (now Institute of Microbiology } \\
\text { ZAS); CBS, Centraalbureau voor Schimmelcultures, Delft, The Netherlands; CCY, Czechoslovak Collection of Yeasts, In- } \\
\text { itute of Chemistry SAS, Bratislava, Czechoslovakia; IBPM, Institute of Biochemistry and Physiology of Microorganisms, Academy } \\
\text { Sciences USSR, Pushcino on Oka, U.S.S.R.; IFO, Institute of Fermentation, Osaka, Japan; LKB, Laboratorium of Kodama } \\
\text { rewing, litagawa, Japan; MGU, State University of Moscow, U.S.S.R.; NRRL, Northern Regional Research Laboratory, Peoria, } \\
\text { linois, U.S.A.; VKM, All Union Collection of Microorganisms, Institute of Microbiology AS USSR, Moscow, U.S.S.R. }\end{array}$} \\
\hline
\end{tabular}

$w / w$, extract) were measured. The ratio of length:width indicates the form of the average cell, and the correlation coefficients between lengths and widths indicate the degree of the ploidy (Sarachek, 1958; Scheda, 1963; Kocková-Kratochvílová \& Pokorná, 1964; Pokorná \& Kocková-Kratochvílová, 1965).

Culture morphology. Pseudomycelium was demonstrated on slides with onion agar (250 g peeled onion was boiled with $\mathrm{I} I$ water, filtered and $\mathrm{I} g$ glucose $1^{-1}$ and $15 \mathrm{~g}$ agar $\mathbf{1}^{-1}$ were added) by a method described by Langeron (1945). For the description of growth in liquid media, beer wort was used. Giant colonies on wort agar were studied during 3 weeks cultivation at room temperature; the diameter of the colony was measured after I, 7, I4 and 2I days and the average radial growth rate was calculated as the increase in diameter $(\mathrm{mm})$ in $100 \mathrm{~h}$.

Physiological characters. Growth at 5 and $42^{\circ} \mathrm{C}$ on wort agar was compared visually with cultures grown at $28^{\circ} \mathrm{C}$. Sporulation activity was estimated on Fowell agar containing $5 \mathrm{~g}$ sodium acetate $\mathrm{l}^{-1}$ by counting the number of sporulation elements (spores, asci, zygotes) within a set of 500 cells. Tolerance to ethanol was studied in beer wort containing $\mathrm{I}, 4,8,12, \mathrm{I} 6$ or $18 \%(\mathrm{v} / \mathrm{v})$ ethanol and the growth limiting concentration was noted. Osmophily was determined in a solution of $4 \mathrm{~g}$ powdered yeast extract $\mathbf{1}^{-1}$ containing either $600 \mathrm{~g}$ sucrose $1^{-1}$ or $100 \mathrm{~g}$ glucose $\mathrm{1}^{-1}$ and $50 \mathrm{~g} \mathrm{NaCl}^{-1}$; growth was compared with that in yeast extract containing $20 \mathrm{~g}$ glucose $\mathrm{I}^{-1}$ by measuring turbidity in a nephelometer. Halophily was tested in medium containing $4 \mathrm{~g}$ yeast extract $\mathrm{l}^{-1}$ supplemented with $20 \mathrm{~g}$ glucose $\mathrm{l}^{-1}$ and 100,150 or $200 \mathrm{~g} \mathrm{NaCl}^{-1}$. Vitamin requirement was tested in Difco Bacto-vitamin-free yeast base; the culture was transferred twice into fresh medium with a I week interval and the turbidity of the culture was then compared with that of a culture grown in medium supplemented with vitamins (Lodder, 1970, p. 82). The autolysis rate was measured on 3-day-old yeast cultures from wort agar; yeast cells corresponding to about I $\mathrm{mg}$ dry wt were transferred into $15 \mathrm{ml}$ distilled water, incubated for $17 \mathrm{~h}$ at $50^{\circ} \mathrm{C}$, centrifuged, and then the content of amino-nitrogen in the supernatant was determined by a method described by Herbert, Phipps \& Strange (197I). Catalase activity was measured according to Lang \& Böhm (I96I), the remaining $\mathrm{H}_{2} \mathrm{O}_{2}$ being determined by titration with $\mathrm{KMnO}_{4}$; the catalase in control samples was inactivated by simultaneous incubation at $100{ }^{\circ} \mathrm{C}$. The phosphomolybdic acid test was carried out according to Holland \& Kunz (196I) and Kocková-Kratochvílová \& Vojtková-Lepšíková (1963) on agar medium containing $10 \mathrm{~g}$ peptone $\mathrm{1}^{-1}, 40 \mathrm{~g}$ sucrose $\mathrm{1}^{-1}$, and $15 \mathrm{~g}$ agar $1^{-1}$, supplemented with $125 \mathrm{~g}$ phosphomolybdic acid $1^{-1}$; the colour of the smear was recorded after 3 days incubation at $28^{\circ} \mathrm{C}$. 


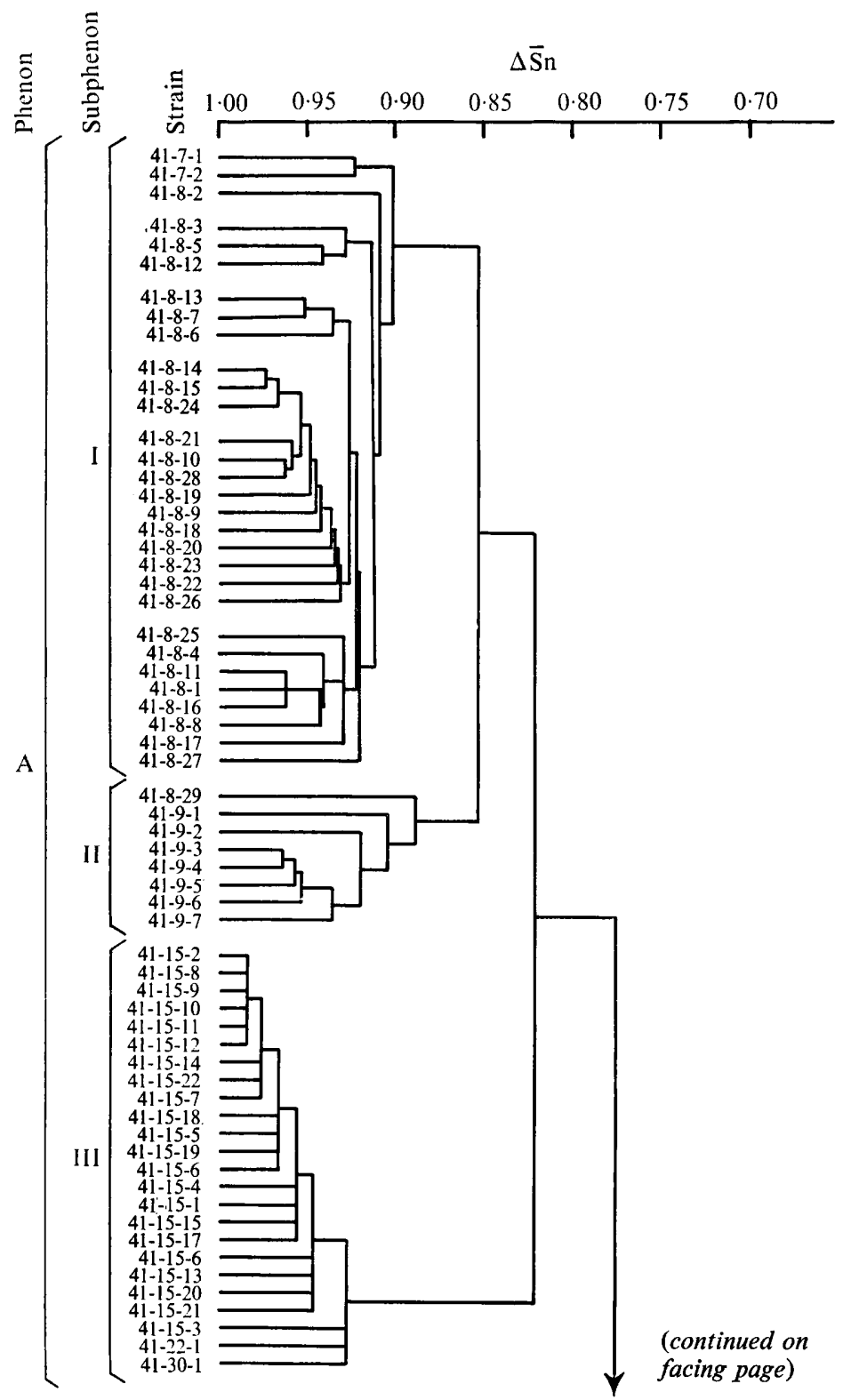

Fig. I. Dendrogram of strains of the genus Debaryomyces. Phenons and subphenons: AI cantarellii, AII castellii, AIII formicarius, BI hansenii, BII tyrocola, BIII coudertii, C torulaspora, D tamarii. 


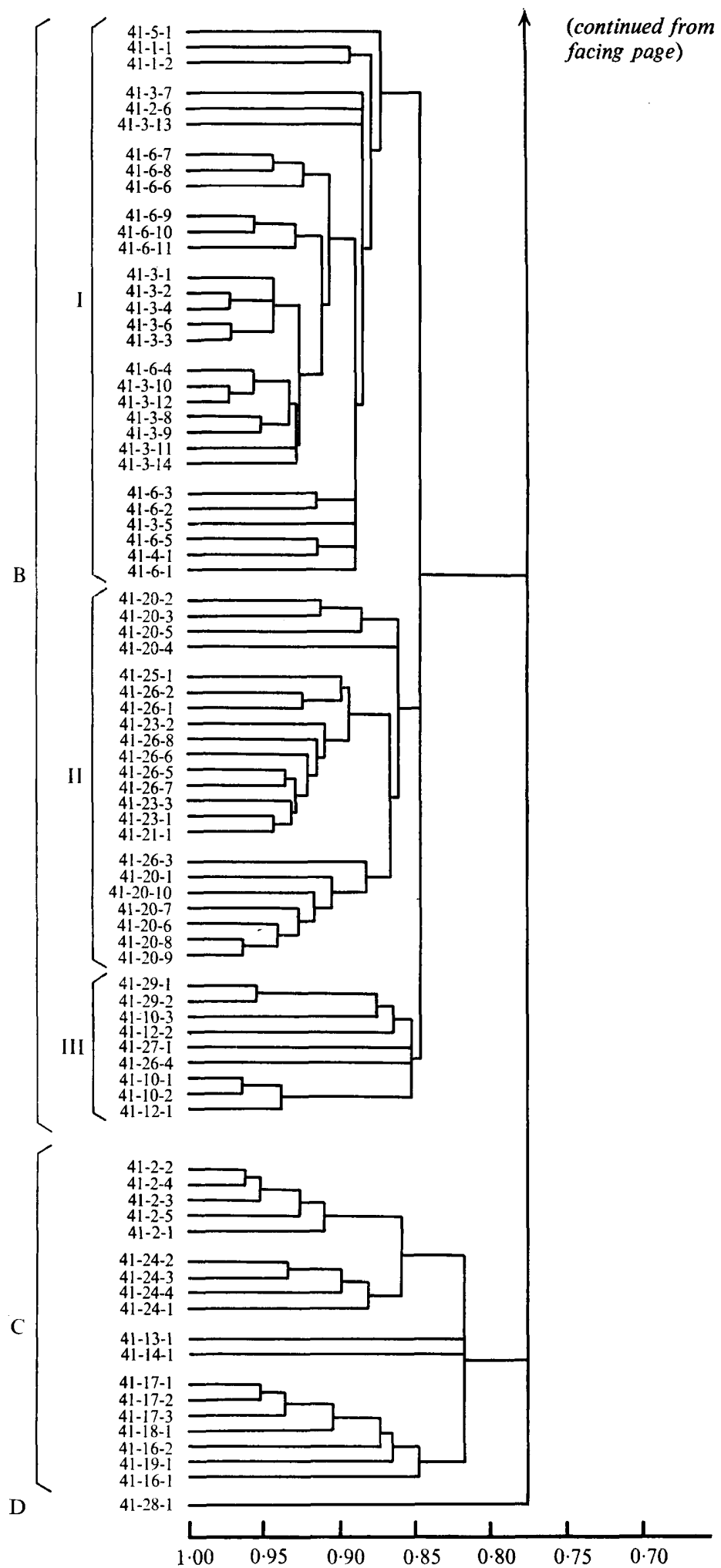


Fermentation and assimilation tests. Fermentation of sugars was tested in Durham tubes containing $4 \mathrm{~g}$ powdered yeast extract $1^{-1}$ and $20 \mathrm{~g}$ sugar $1^{-1}$. Assimilation of sugars and other carbon and nitrogen sources was tested using Difco Bacto-yeast carbon base or Bacto-yeast nitrogen base agar on the surface of which were placed filter paper discs, which had been soaked with $50 \mathrm{~g}$ test substance $\mathrm{1}^{-1}$ and sterilized by ultraviolet light.

The utilization of raffinose is an important taxonomic character and depends on the presence of the enzymes $\beta$-fructofuranosidase, $\alpha$-glucosidase and $\alpha$-galactosidase. Metabolic products of raffinose (D-galactose, melibiose and sucrose) were determined chromatographically (Kocková-Kratochvílová, Vojtková-Lepšiková \& Fischerová, 1959) using diphenylamine for detection.

The assimilation of ethanol, ethanediol and glycerol was evaluated in liquid medium with the alcohol as sole source of carbon using Bacto-yeast nitrogen base. The assimilation of $n$-alkanes $\left(C_{6}\right.$ to $\left.C_{16}\right)$ was tested as described by Markowetz \& Kallio (1964). The growth on Bacto-yeast nitrogen base agar was compared visually with control samples on the same medium containing glucose as a carbon source.

Serological tests. Rabbit sera against Debaryomyces hansenii CCY4I-6-2 and Pichia membranaefaciens CCY39-1-4 were kindly supplied by Dr J. Sandula; the simple agglutination test was done in tubes.

Effect of inhibitory substances. Inhibition by actidione was estimated by the disc method (I, 50 or $100 \mu \mathrm{g}$ actidione per disc), measuring the diameter of the clear zone around the disc after incubation on beer wort agar at $28{ }^{\circ} \mathrm{C}$. The inhibitory effect of $20 \mathrm{~g}$ DL-lactic acid $\mathrm{l}^{-1}$ or $20 \mathrm{~g} \mathrm{DL}$-tartaric acid $\mathrm{I}^{-1}$ was measured nephelometrically in a medium containing $4 \mathrm{~g}$ powdered yeast extract $1^{-1}$ and $20 \mathrm{~g}$ glucose $\mathrm{l}^{-1}$ by comparing the absorbance of the test broth with that of a control.

Coding of features for computation. Features existing in two mutually exclusive states were scored as I or 0 . Other qualitative features were divided into three or more mutually exclusive states, e.g. character of giant colonies, growth in liquid media, type of pseudomycelium. Multistate quantitative characters were divided into states according to the frequency distribution curves, e.g. cell sizes, radial growth rate, inhibition tests. The non-additive code in the $o$ and I scale was used for more than two-state characters.

Computation. The similarity between strains was computed by the 'matching' coefficient method of Sokal \& Michener (1958); both positive and negative matches were included. This coefficient $\left(\mathbf{S}_{\mathrm{SM}}\right)$ was calculated from the equations:

$$
\begin{array}{r}
\mathrm{S}_{\mathrm{SM}}=\mathrm{I}-d_{\mathrm{jk}}^{2} \\
n \\
\text { and } d_{\mathrm{jk}}^{2}=\frac{\sum_{1}^{n}\left(x_{\mathrm{j}}-x_{\mathrm{k}}\right)^{2}}{n}
\end{array}
$$

(which are valid for the o-I scale used) where $x_{\mathrm{j}}$ and $x_{\mathrm{k}}$ are matches for strains $\mathrm{j}$ and $\mathrm{k}, \boldsymbol{n}$ is the number of matches included in the calculation and $d_{\mathrm{jk}}$ is the taxonomic distance between strains $\mathrm{j}$ and $\mathrm{k}$. The dendrogram was prepared by the method of unweighted average linkage (Sokal \& Sneath, 1963). The homogeneity of clusters was checked using the $\chi^{2}$ test. Single phenons at the $77 \%$ similarity level were characterized according to the percentage frequency of positive characters (Goodfellow, I97I). The individual phenons were named according to the centroid strain or group of strains.

The calculations were programmed in Algol and carried out on the Gier III computer at the Institute of Technical Cybernetics of the Slovak Academy of Sciences, Bratislava.

\section{RESULTS AND DISCUSSION}

\section{Formation of phenons}

The 142 strains of the genus Debaryomyces were classified into three phenons (A, B and C) and one individual strain (phenon D) at the $77.7 \%$ similarity level (Fig. I). Phenon A contained 62 strains and was divided at the level of $82.2 \%$ of average similarity into three subphenons: I, cantareilii; II, castellii; and III, formicarius. Phenon B contained 6I strains and was divided at the level of $84.6 \%$ of average similarity into three subphenons: I, hansenii; II, tyrocola; and III, coudertii. Phenon C contained I 8 strains at the level of $8 \mathrm{I} \cdot 8 \%$ of average similarity and was named torulaspora. (It was given this name because most of the strains originally described as of the genus Torulaspora were included in this phenon.) The individual strain, the type culture of $D$. tamarii, will be the subject of a future communication. 
Table 2. Percentage frequency of positive characters found in individual phenons at the $80 \%$ similarity level

Character

Cell morphology:

Average cell length

$$
<5.5 \mu \mathrm{m}
$$$$
5 \cdot 6-7.5 \mu \mathrm{m}
$$$$
>7.5 \mu \mathrm{m}
$$

Average cell width

$$
<4.0 \mu \mathrm{m}
$$$$
4 \cdot \mathrm{I}-5 \cdot 0 \mu \mathrm{m}
$$

$$
>5.0 \mu \mathrm{m}
$$

Length:width ratio

$\mathrm{I} \cdot \mathrm{O}-\mathrm{I} \cdot \mathrm{IO}$

I. II I-I.5O

$>\mathrm{I} \cdot 50$

Surface:volume ratio

$$
\begin{aligned}
& <\mathrm{I} \cdot \mathrm{O} \\
& \mathrm{I} \cdot \mathrm{OI}-\mathrm{I} \cdot 30 \\
& >\mathrm{I} \cdot 30
\end{aligned}
$$

Phenon A

$\overbrace{*(30)}^{\text {I }} \quad \underset{(8)}{\text { II }} \quad \underset{(24)}{\text { III }}$

$\overbrace{\begin{array}{c}\text { I } \\ (30)\end{array}{\underset{(22)}{\text { II }}}_{(2)}^{\text {III }}}^{\text {Phenon B }}$

Phenon C'

Correlation coefficient between lengths and widths of cells

$$
\begin{aligned}
& 0-0.30 \\
& 0.31-0.60 \\
& 0.61-1.00
\end{aligned}
$$

Culture morphology:

Pseudomycelium

$$
\text { None }
$$

Rudimentary

Dendroidal

Growth in $7 \%(w / v)$ beer wort

Sediment only

Ring

Islets on surface

Pellicle

$\begin{array}{rrrrrrr}6 & 0 & 0 & 100 & 72 & 88 & 28 \\ 80 & 87 & 75 & 0 & 28 & 12 & 72 \\ 14 & 13 & -25 & 0 & 0 & 0 & 0\end{array}$

600

$80 \quad 0 \quad 13$

I4 IOO

50

50

19

59

○ $75 \quad 0$

$\begin{array}{rrr}67 & 25 & 93 \\ 33 & 0 & 7\end{array}$

50

$22 \quad 12$

66

$\begin{array}{rrr}3 & 0 & 25 \\ 83 & 100 & 75\end{array}$

47

$45 \quad 77$

$\begin{array}{lll}55 & 39\end{array}$

3

0

0$$
\text { I4 }
$$

$\begin{array}{rr}3 & \text { I } 3 \\ 27 & 37\end{array}$

$\begin{array}{ll}70 & 50\end{array}$

0
33
67

0
10

10
90

13
28

0
100

59

$0 \quad 0$

$12 \quad 72$

$88 \quad 28$

Giant colonies

Smooth

Semi-rough

Rough

Radial growth rate $\left[\mathrm{mm}(100 \mathrm{~h})^{-1}\right]$

$$
\begin{aligned}
& <3.0 \\
& 3.1-5.0 \\
& 5.1-7.0 \\
& >7.0
\end{aligned}
$$

Growth at $5^{\circ} \mathrm{C}$ :

None

Moderate

Good

Growth at $42{ }^{\circ} \mathrm{C}$ :

None

Weak

Good

Tolerance to ethanol $(\%, v / v$, in medium):<smiles>[CH]</smiles>

I 2

$\begin{array}{rrrrrrr}0 & 13 & 8 & 56 & 86 & 100 & 88 \\ 53 & 13 & 70 & 23 & 10 & 0 & 0 \\ 47 & 74 & 22 & 21 & 4 & 0 & 12\end{array}$

$\begin{array}{lllllll}0 & 0 & 0 & 20 & 9 & 22 & 28\end{array}$

$\begin{array}{lllllll}36 & 75 & 17 & 43 & 73 & 78 & 72\end{array}$

$\begin{array}{lllllll}33 & 25 & 71 & 6 & 0 & 0 & 0\end{array}$

$\begin{array}{lllllll}31 & 0 & 12 & 31 & 18 & 0 & 0\end{array}$

$\begin{array}{lllllll}40 & 87 & 30 & 60 & 90 & 100 & 66\end{array}$

$\begin{array}{rrrrrrr}60 & 13 & 70 & 33 & 5 & 0 & 28 \\ 0 & 0 & 0 & 7 & 5 & 0 & 6\end{array}$

$\begin{array}{rrrrrrr}0 & 0 & 7 & 7 & 0 & 0 & 28 \\ 33 & 25 & 43 & 66 & 63 & 66 & 72 \\ 67 & 62 & 50 & 25 & 37 & 22 & 0 \\ 0 & 13 & 0 & 2 & 0 & 12 & 0\end{array}$

$\begin{array}{rrrrrrr}0 & 0 & 100 & 0 & 0 & 0 & 28 \\ 96 & 100 & 0 & 83 & 77 & 100 & 72\end{array}$

$\begin{array}{rrrrrrr}4 & 0 & 0 & 17 & 23 & 0 & 0\end{array}$

$\begin{array}{lllllll}70 & 100 & 4 & 70 & 59 & 23 & \text { I I }\end{array}$

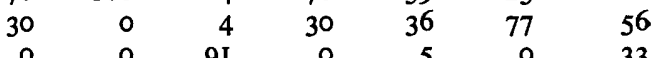

$\begin{array}{lllllll}96 & 100 & 79 & 93 & 36 & 66 & 56\end{array}$

$\begin{array}{rrrrrrr}4 & 0 & 21 & 93 & 36 & 66 & 56 \\ 0 & 0 & 0 & 0 & 59 & 23 & 44\end{array}$

Growth in $60 \%(w / v)$ sucrose:

$$
\begin{aligned}
& <30 \% \\
& 30-60 \% \\
& 60-80 \% \\
& 80-100 \%
\end{aligned}
$$


Table 2 (cont.)

Character

Phenon A

Phenon B Phenon C

Growth in $10 \%(w / v)$ glucose and $5 \%$ $(\mathrm{w} / \mathrm{v}) \mathrm{NaCl}:$

$<30 \%$

$30-60 \%$

$60-80 \%$

$80-100 \%$

Halophily:

No growth in $10 \% \mathrm{NaCl}$

Growth in $10 \% \mathrm{NaCl}$

$$
\begin{aligned}
& 15 \% \mathrm{NaCl} \\
& 20 \% \mathrm{NaCl}
\end{aligned}
$$

Growth in vitamin-free medium $(\%$ of growth in supplemented medium):

$$
\begin{aligned}
& 15-50 \\
& 5 \mathrm{I}-90 \\
& 9 \mathrm{I}-100
\end{aligned}
$$

Autolysis rate [mg amino-N (I00 mg dry $w t)^{-1}$ ]:

$$
<\mathrm{I} \cdot \mathrm{O}
$$

$$
>\mathrm{I} \cdot \mathrm{O}
$$

Fermentation of:

Glucose

Galactose

Sucrose

Maltose

Lactose

Assimilation of:

Galactose

Sucrose

Maltose

Lactose

Melibiose

Trehalose

Cellobiose

Melezitose

Maltotriose $\uparrow$

Starch

Sorbose

Xylose

Arabinose

Rhamnose

Ribose

Inulin

Mannitol

Galactitol

Ribitol

Arabitol

Erythritol

Glucitol

Ethanol

Ethanediol

Glycerol

Lysine

Utilization of $n$-alkanes:

Slight or none

Moderate

Strong

Metabolic end products of raffinose:

Meiibiose

D-Galactose

No detectable sugar

No assimilation

$\overbrace{\text { I II III }} \overbrace{\text { I II }}^{\text {III }}$

$\begin{array}{rrrrrrr}0 & 0 & 0 & 4 & 0 & 0 & 0 \\ 0 & 0 & 0 & 8 & 5 & 11 & 6 \\ 50 & 13 & 0 & 46 & 23 & 56 & 0 \\ 50 & 87 & 100 & 42 & 72 & 33 & 94 \\ 76 & 13 & 91 & 43 & 9 & 44 & 100 \\ 24 & 87 & 0 & 43 & 36 & 12 & 0 \\ 0 & 0 & 4 & 14 & 41 & 44 & 0 \\ 0 & 0 & 4 & 0 & 14 & 0 & 0\end{array}$

$\begin{array}{rrrrrrr}0 & 100 & 0 & 93 & 100 & 100 & 17 \\ 0 & 0 & 9 & 7 & 0 & 0 & 83 \\ 100 & 0 & 91 & 0 & 0 & 0 & 0\end{array}$

$\begin{array}{rrrrrrr}30 & 87 & 70 & 93 & 95 & 100 & 77 \\ 70 & 13 & 30 & 7 & 5 & 0 & 23 \\ 100 & 100 & 100 & 13 & 13 & 44 & 100 \\ 0 & 0 & 0 & 0 & 0 & 0 & 27 \\ 93 & 100 & 0 & 10 & 4 & 44 & 94 \\ 0 & 0 & 0 & 0 & 0 & 0 & 0 \\ 0 & 0 & 0 & 0 & 0 & 0 & 0\end{array}$

$\begin{array}{lllllll}100 & 75 & 100 & 100 & 100 & 88 & 38\end{array}$

$\begin{array}{lllllll}100 & 100 & 100 & 100 & 100 & 100 & 94\end{array}$

$\begin{array}{lllllll}100 & 100 & 100 & 100 & 100 & 100 & 44\end{array}$

$\begin{array}{lllllll}83 & 87 & 0 & 23 & 40 & 55 & 6\end{array}$

$\begin{array}{rrrrrrr}97 & 100 & 100 & 16 & 93 & 74 & 54\end{array}$

$\begin{array}{lllllll}100 & 100 & 100 & 93 & 100 & 100 & 66\end{array}$

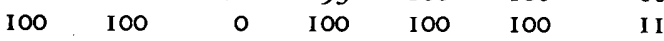

$\begin{array}{lllllll}100 & 87 & 100 & 100 & 100 & 100 & 50\end{array}$

$\begin{array}{lllllll}76 & 100 & 100 & 30 & 45 & 77 & 16\end{array}$

$\begin{array}{lllllll}100 & 100 & 100 & 86 & 55 & 0 & 0\end{array}$

$\begin{array}{lllllll}100 & 100 & 100 & 16 & 93 & 100 & 100\end{array}$

$\begin{array}{lllllll}100 & 100 & 100 & 93 & 86 & 100 & 22\end{array}$

$\begin{array}{lllllll}0 & 12 & 0 & 76 & 100 & 66 & 22\end{array}$

$\begin{array}{lllllll}0 & 12 & 100 & 46 & 18 & 66 & 27\end{array}$

$\begin{array}{llllll}26 & 12 & 50 & 73 & 13 & 22\end{array}$

$\begin{array}{lllllll}0 & 0 & 0 & 4 & 0 & 0 & 16\end{array}$

$\begin{array}{lllllll}100 & 100 & 100 & 96 & 100 & 100 & 88\end{array}$

$\begin{array}{lllllll}56 & 0 & 29 & 0 & 13 & 0 & 0\end{array}$

$\begin{array}{lllllll}100 & 100 & 100 & 93 & 72 & 100 & \text { I I }\end{array}$

$\begin{array}{lllllll}100 & 100 & 100 & 96 & 100 & 100 & 50\end{array}$

$100 \quad 50 \quad 100 \quad 96 \quad 50 \quad 55 \quad 5$

$\begin{array}{lllllll}100 & 100 & 100 & 96 & 90 & 100 & 44\end{array}$

$\begin{array}{lllllll}100 & 87 & 100 & 36 & 40 & 55 & 27\end{array}$

$\begin{array}{lllllll}46 & 0 & 4 & 0 & 0 & 0 & 0\end{array}$

$\begin{array}{lllllll}100 & 100 & 100 & 10 & 95 & 45 & 33\end{array}$

$\begin{array}{lllllll}100 & 100 & 100 & 93 & 100 & 88 & 83\end{array}$

$\begin{array}{lllllll}5 & 0 & 0 & 77 & 77 & 100 & 100\end{array}$

$\begin{array}{rrrrrrr}5 & 0 & 0 & 23 & 18 & 0 & 0 \\ 90 & 100 & 100 & 0 & 5 & 0 & 0\end{array}$

$\begin{array}{lllllll}3 & 0 & 4 & 5 I & 7 & 30 & 83\end{array}$

$\begin{array}{rrrrrrr}0 & 0 & 0 & 23 & 7 & \text { I I } & 0 \\ 97 & 100 & 96 & 26 & 86 & 44 & \text { I I } \\ 0 & 0 & 0 & 0 & 0 & \text { I 5 } & 6\end{array}$ 
Table 2 (cont.)

Character

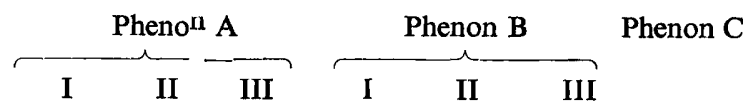

Inhibition by:

Actidione $(50 \mu \mathrm{g} / \mathrm{disc})$ (diam. of clear zone, $\mathrm{mm}$ )

No inhibition

I-I 5

I6-20

$>20$

DL-Lactic acid $(2 \%, w / v)(\%$ of growth of control)

$<$ IO

II -50

$5 I-100$

$>100$

DL-Tartaric acid $(2 \%, w / v)(\%$ of growth of control)

$<10$
$1 \mathrm{I}-50$
$5 \mathrm{I}-100$

$>100$

Sporulation activity ( $\%$ sporulation elements):

None

$<$ IO

$10-50$

$$
>50
$$

Catalase activity $\left[\% \mathrm{H}_{2} \mathrm{O}_{2}\right.$ metabolized

(mg dry wt) ${ }^{-1} \mathrm{~min}^{-1}$ ]:

$<47$

$4 \cdot 75-5 \cdot 8$

$5 \cdot 85-9 \cdot 0$

$>9.0$

Colour of streak on phosphomolybdic acid

agar:

White

Olive

Brown

Blue

Dark blue

Agglutination with rabbit sera against:

$\begin{array}{rrrrrrr}100 & 100 & 100 & 33 & 5 & 0 & 23 \\ 0 & 0 & 0 & 26 & 5 & 22 & \text { I I } \\ 0 & 0 & 0 & 15 & 5 & 22 & 5 \\ 0 & 0 & 0 & 26 & 86 & 56 & 6 \text { I } \\ & & & & & & \\ 0 & 0 & 0 & 4 & 40 & 12 & 5 \\ 0 & 75 & 0 & 83 & 50 & 88 & 18 \\ 83 & 25 & 34 & 10 & 10 & 0 & 72 \\ 17 & 0 & 66 & 4 & 0 & 0 & 5\end{array}$

D. hansenii CCY4I-6-2

No agglutination

Dilution titre 20-80

Dilution titre $160-320$

$\begin{array}{rrrrrr}25 & 0 & 17 & 14 & 0 & 17 \\ 62 & 4 & 83 & 86 & 100 & 50 \\ 13 & 50 & 0 & 0 & 0 & 33 \\ 0 & 46 & 0 & 0 & 0 & 0\end{array}$

87

$\begin{array}{ll}4 & 87\end{array}$

$80 \quad 13$

16

$\begin{array}{rrrrr}0 & 90 & 96 & 70 & 60 \\ 0 & 10 & 4 & 11 & 33 \\ 30 & 0 & 0 & 19 & 9 \\ 70 & 0 & 0 & 0 & 0\end{array}$

$P$. membranaefaciens CCY39-I-4

No agglutination

Dilution titre $20-80$

Dilution titre $160-320$

$\begin{array}{rl}0 & \\ 0 & 3 \\ 10 & 6\end{array}$

0
38
62
0

$\begin{array}{rrrrr}87 & 0 & 8 & 0 & 0 \\ 13 & 30 & 30 & 0 & 10 \\ 0 & 70 & 58 & 100 & 90 \\ 0 & 0 & 4 & 0 & 0\end{array}$

$\begin{array}{rrrrrrr}0 & 0 & 0 & 83 & 60 & 11 & 5 \\ 70 & 0 & 8 & 17 & 4 & 11 & 5 \\ 13 & 0 & 0 & 0 & 0 & 0 & 0 \\ 10 & 0 & 4 & 0 & 30 & 0 & 72 \\ 7 & 100 & 88 & 0 & 6 & 78 & 18\end{array}$

$*$ Numbers of strains analysed are given in parentheses.

$\dagger$ Maltotriose was only weakly assimilated by the percentages of strains indicated.

\section{Characteristics of the phenons}

The characteristics of the taxa are given in Table 2. The characters which differentiate phenons $\mathrm{A}, \mathrm{B}$ and $\mathrm{C}$ are given in Table 3 . Whilst phenon $\mathrm{C}$ is clearly separated from the other two, phenons A and B are only reliably separated on the basis of their different GC contents. The difference, however, is slight and further evaluation of the position of these phenons is probably required. 
Table 3. Characters for differentiating between individual phenons

\begin{tabular}{|c|c|c|c|c|}
\hline \multirow[b]{2}{*}{ Phenon } & \multirow[b]{2}{*}{ Subphenon } & \multirow[b]{2}{*}{ GC content $(\mathrm{mol} \%)$} & \\
\hline & & & Starch & $n$-Alkanes \\
\hline $\begin{array}{l}\mathbf{A} \\
\mathbf{B}\end{array}$ & $\begin{array}{l}\text { I, II, III } \\
\text { I } \\
\text { II } \\
\text { III }\end{array}$ & $\left\{\begin{array}{l}32 \cdot 4-34 \cdot 4 \\
36 \cdot 6-37 \cdot 3\end{array}\right.$ & $\begin{array}{l}+ \\
+ \\
+1- \\
-\end{array}$ & $\begin{array}{l}+ \\
+ \\
+ \\
-\end{array}$ \\
\hline $\mathrm{C}$ & & $42 \cdot 9-45 \cdot 6$ & - & - \\
\hline
\end{tabular}

Table 4. Characters for differentiating between individual subphenons within phenon $A$

$\begin{array}{lccc}\text { Character } & \begin{array}{c}\text { Subphenon I } \\ \text { Elongate } \\ \text { Rudimentary }\end{array} & \begin{array}{c}\text { Subphenon II } \\ \text { Slightly ovoid } \\ \text { Dendroidal }\end{array} & \begin{array}{c}\text { Subphenon III } \\ \text { Ellipsoidal } \\ \text { Rudimentary }\end{array} \\ \text { Pseudomycelium } & + & + & - \\ \text { Growth at } 5^{\circ} \mathbf{C} & - & - & + \\ \text { Growth at } 4 \mathbf{C}^{\circ} \mathrm{C} & + & - & + \\ \text { Growth in vitamin-free medium } & + & + & - \\ \text { Fermentation of sucrose } & +- & + & - \\ \text { Assimilation of lactose } & + & + & - \\ \text { Assimilation of cellobiose } & - & - & + \\ \text { Assimilation of rhamnose } & + & - & + \\ \text { Tolerance* to lactic acid } & + & - & + \\ \text { Tolerance* to tartaric acid } & \text { Weak } & \text { Weak } & >50 \% \\ \text { Sporulation activity } & \text { Olive } & \text { Dark blue } & \text { Dark blue } \\ \text { Colour of streak on phosphomolybdic } & & \end{array}$

\footnotetext{
+ , Present; - , absent

* Growth not markedly inhibited, i.e. $>50 \%$ of control.
}

The distinctive features of each phenon are as follows:

Phenon $A$. Cells are ellipsoidal to elongated, tend to form dendroidal pseudomycelium, have a fast radial growth rate, low tolerance to ethanol, $60 \%$ sucrose and $10 \% \mathrm{NaCl}$, are resistant to actidione, lactic acid and tartaric acid, and are agglutinated by $P$. membranaefaciens antiserum.

Phenon $B$. Cells are spherical to slightly ellipsoidal with a high surface:volume ratio and a high correlation coefficient between cell length and width. They have no pseudomycelium, are able to grow at $5{ }^{\circ} \mathrm{C}$, but grow only slightly or not at all at $42{ }^{\circ} \mathrm{C}$. They require vitamins, slowly autolyse and show very weak or no fermentation of glucose and sucrose, but assimilate arabinose. They do not sporulate, and are sensitive to actidione, lactic acid and tartaric acid.

Phenon $C$. Cells are spherical or ellipsoidal, their surface:volume ratio is between $\mathrm{I} \cdot 0$ and $\mathrm{I} \cdot 3$, in keeping with diploid cells, and they have a high correlation coefficient between cell length and width. They have no pseudomycelium, have a slow radial growth rate, high osmophily and low halophily, rapidly ferment glucose, galactose and sucrose, assimilate sorbose but not soluble starch or galactitol, are sensitive to actidione, turn phosphomolybdic acid medium blue, and do not agglutinate with $D$. hansenii or $P$. membranaefaciens antiserum.

The characters for differentiating the three subphenons of phenon $\mathrm{A}$ are given in Table 4. The subphenons of phenon B could be differentiated on the basis of their different catalase activities and colour produced on phosphomolybdic acid medium (see Table 2).

Phenon $\mathbf{C}$ resembles those groups of Saccharomyces sensu lato in which two proliferating cells unite before ascus formation, i.e. S. bailii, S. fermentati, S. delbrueckii (KockováKratochvílová \& Nakase, 197I; Kocková-Kratochvilová, 1976). The GC content of these Saccharomyces groups varies from $40 \cdot 0$ to $44.1 \mathrm{~mol} \%$ (Yarrow \& Nakase, I975). A number of other morphological and physiological features of these Saccharomyces groups and 
phenon $\mathrm{C}$ are also similar. We therefore propose to combine the above mentioned groups into one group named torulaspora, which corresponds to the genus Torulaspora Lindner in classical taxonomy.

Recently, the heterogeneity of Saccharomyces, Debaryomyces and related genera has been discussed. Yarrow \& Nakase (I975) reported the GC content of 48 species of Saccharomyces sensu lato and classified these strains into four groups, only the first of which could be considered as Saccharomyces sensu stricto. Similarly, van der Walt \& Johannsen (1975) proposed the name Torulaspora Lindner for a number of different species, including the whole genus Debaryomyces. Kurtzman \& Baker (1975) published scanning electron micrographs of spores of various strains previously classified in the genus Saccharomyces ( $S$. pretoriensis, $S$. microellipsodes) and demonstrated the rough surface of their spore walls, a characteristic which is sufficient for separating these species from Saccharomyces sensu stricto.

We thank Mrs L. Hronská and Mrs Jurčová for their excellent technical assistance, and Dr I. P. Babyeva, Dr N. Fateyeva, Dr K. Kodama and Dr R. de Miranda for kindly supplying cultures.

\section{REFERENCES}

Gezelius, K. \& Norkrans, B. (1970). Ultrastructure of Debaryomyces hansenii. Archiv für Mikrobiologie 70, 14-25.

GoODFELLOW, M. (I97I). Numerical taxonomy of some nocardioform bacteria. Journal of General Microbiology 69, 33-80.

Herbert, D., Phipps, P. J. \& Strange, R. E. (I97I). Chemical analysis of microbial cells. Methods in Microbiology 5B, 256-258.

HollaNd, M. L. \& KUNZ, L. J. (196I). Evaluation of molybdate agar as a selective differential medium for yeasts. Journal of Bacteriology 81, 869-874.

KoCKovÁ-Kratochvílová, A. (1976). Taxometric study of the genus Saccharomyces (Meyen) Reess. 3rd part: Small species. Biologické práce, Bratislava XXII/6.

Kocková-Kratochvílová, A. \& Nakase, T. (197I). Vergleichende Taxonomie der Gattung Saccharomyces (Meyen) Reess. Zeitschrift für allgemeine Mikrobiologie II, 35-38.

Kocková-Kratochvílová, A. \& Pokorná, M. (1964). Species morphotypisation of the Saccharomyces genus. Biológia, Bratislava 19, 778791 .

Kocková-Kratochvílová, A., Šandula, J., VoJTKOVÁ-LEPŠíKOVÁ, A., SEDLÁROVÁ, L. \& KASMANOVÁ, M. (1969). Taxometric study of the genus Saccharomyces (Meyen) Reess. I. Saccharomyces carlsbergensis Hansen and related species. Biologické práce, Bratislava XV/I.

Kocková-Kratochvílová, A. \& VoJTKovÁLePšíkovÁ, A. (1963). The genus Candida Berkhout. IV. The importance of the phosphomolybdic acid test for the identification of Candida species. Československá epidemiologie, mikrobiologie a immunologie 12, 184-187 (in Slovak).

KOCKOVÁ-KRATOCHVÍLOVÁ, A., VotJKOVÁ-LePŠíková, A. \& Fischerová, M. (1959). Die Art der Zuckerverwertung durch die Hefe und hefeartige Mikroorganismen. Brauwissenschaft I2, I IO-I 43 .
Komagata, K., Nakase, T. \& Katsuya, N. (I964). Assimilation of hydrocarbons by yeasts. I. Preliminary screening. Journal of General and Applied Microbiology ro, 31 3-321.

Kurtzman, C. P. \& BakeR, F. L. (1975). Scanning electron microscopy of ascospores of Debaryomyces and Saccharomyces. Mycopathologia and mycologia applicata 55, 29-34.

LANG, W. \& BöHN, E. (196I). Untersuchungen über die Thermolabilität der Bakterienkatalase. Biochemische Zeitschrift 335, 75-85.

Langeron, M. (1945). Précis de Mycologie, pp. 467-468. Paris: Masson.

LoDDER, J. (1970). The Yeasts, a Taxonomic Study. Amsterdam: North Holland Publishing Co.

Markowetz, A. J. \& Kallio, R. E. (1964). Assimilation of alkanes and alkenes by yeasts. Journal of Bacteriology 87, 968-969.

NoRKRANS, B. (1966). Studies on marine occurring yeasts: growth related to $\mathrm{pH}, \mathrm{NaCl}$ concentration and temperature. Archiv für Mikrobiologie 54, 374-392.

NoRKRANS, B. (1968). Studies on marine occurring yeasts: respiration, fermentation and salt tolerance. Archiv für Mikrobiologie 62, 358-372.

NoRkRANS, B. \& KYLIN, A. (1969). Regulation of the potassium to sodium ratio and of the osmotic potential in relation to salt tolerance in yeasts. Journal of Bacteriology roo, 836-845.

Pokorná, M. \& Kocková-Kratochvílová, A. (1965). Nomogram for determining the surface/ volume ratio of cells. Biologia, Bratislava 20, $552-553$.

RAO, B. V. \& BHAT, J. V. (197I). Characteristics of yeasts isolated from phenol and catechol-adapted activated sludges. Antonie van Leeuwenhoek 37, 303-312.

SARACHEK, A. (1958). The free amino acid contents and growth rates of polyploid Saccharomyces. Experientia 14, 360-365.

ScHEDA, R. (1963). Untersuchungen über die Maltose- und Glukosevergärung bei homo- 
zygoten Hefestämmen mit verschiedenen Genomzahlen. Archiv für Mikrobiologie 45, 65-100.

SchedA, R. \& Bos, P. (I966). Hydrocarbons as substrate for yeasts. Nature, London $2 \mathrm{II}, 660$.

Shavlovsky, G. M., Ksheminskaya, G. P. \& VARIVODA, M. I. (I970). Production of considerable amount of riboflavin by some yeast strains of the Debaryomyces genus. Mikrobiologiya 39, 327-330 (in Russian).

SokAl, R. R. \& Michener, C. D. (1958). A statistical method for evaluating systematic relation- ships. University of Kansas Science Bulletin $\mathbf{3}^{\mathbf{8}}$, 1409-1438.

Sokal, R. R. \& Sneath, P. H. A. (1963). Principles of Numerical Taxonomy. San Francisco and London: W. H. Freeman.

VAN DER WALT, J. P. \& Johannsen, E. (1975). The genus Torulaspora Lindner. South African Council of Scientific Industrial Research Report $\mathbf{3 2 5}$

YARROW, D. \& NAKASE, T. (1975). DNA base composition of species of the genus Saccharomyces. Antonie van Leeuwenhoek 4r, 81-88. 